\title{
Modeling energy flow in a large Neotropical reservoir: a tool do evaluate fishing and stability
}

\author{
Ronaldo Angelini*, Angelo Antonio Agostinho** and Luiz Carlos Gomes**
}

Recently, there is an increasing perception that the ecosystem approach gives important insights to support fisheries stock assessment and management. This paper aims to quantify energy flows in the Itaipu Reservoir (Brazil) and to simulate increase of the fishing effort of some species, using Ecopath with Ecosim software, which could allow inferences on stability. Therefore, two steady-state Itaipu models were built (1983-87 and 1988-92). Results showed that: a) there are no differences between models, and results on aging trends do not vary over time indicating that fishery does not alter the ecosystem as a whole; b) results of fisheries simulations are approximate to mono-specific stock assessment for the same species and periods; c) many authors believe that tropical ecosystems are environments where biotic and abiotic oscillations are annual and sometimes unexpected, but the results found for the Itaipu Reservoir indicate that stability was met after 16 years.

Nos dias atuais, aumenta a percepção que a análise ecossistêmica fornece importantes esclarecimentos na avaliação e manejo de estoques pesqueiros. Este trabalho objetiva quantificar o fluxo de energia na teia trófica do reservatório de Itaipu e simular o aumento de pesca de algumas espécies usando o programa "Ecopath com Ecosim", que permite inferências sobre a estabilidade do sistema. Desta forma, dois modelos de "estado-estacionário" foram construídos (o primeiro para o período 1983-87 e o outro para 1988-92). Os resultados mostraram que: a) não há diferenças entre os modelos e os resultados sobre tendências de amadurecimento não variam com o tempo indicando que a pesca não altera o sistema como um todo; b) os resultados de simulação de pesca se aproximam de avaliações mono-específicas, realizadas por outros autores, com dados de mesmas espécies e períodos; c) muitos autores acreditam que reservatórios tropicais são ambientes submetidos a oscilações antrópicas que alteram grandemente sua dinâmica dificultando a estabilidade, mas os resultados para o reservatório de Itaipu indicam que a estabilidade foi encontrada 16 anos após a sua formação.

Key words: Ecopath, Food web, Fisheries, Ecosystem, Simulation.

\section{Introduction}

Trophic ecosystem models allow measurement of trophic flows among various system components (primary producers, consumers and predators) and provide fundamental information on their influences on recycling, primary production and food web (Christensen, 1995). Foundations of this ecosystem approach were established by Odum (1969) and Lindeman (1942), which described development of systems restricted by the Second Law of Thermodynamics and therefore susceptible to simulation.

Recently, there is an increasing recognition that the ecosystem approach gives important insights to support fish stock assessment and management (Christensen \& Pauly, 1993; Walters et al., 1997; Mace, 2001; Hilborn et al., 2003; FAO, 2003). This new approach is called Ecosystem-Based
Fishery Management (EBFM), and its overall objective is to maintain the health of aquatic ecosystems and the fisheries they support (Pikitch et al., 2004).

Multi-specific policy decisions can be simulated in ecosystem models (Christensen \& Pauly, 1998; Heymans et al., 2004), and comparisons of these models have increased our understanding on ecosystem functioning and fisheries trends (Vasconcellos et al., 1997; Jarre-Teichmann, 1998; Aoki \& Mizushima, 2001; Christensen et al., 2003).

Although most studies on EBFM deal with marine systems, application of this approach in freshwater is important because inland fisheries are apparently more susceptible to environmental changes and play a fundamental role as food source in many countries (FAO, 2002).

Food web simulation in freshwater ecosystems, especially reservoirs, has aided to test several fisheries management

*Universidade Estadual de Goiás - UnUCET, Laboratório de Biodiversidade do Cerrado, BR 153 Km 98, Jd. Arco Verde, CP 459, 75074840 Anápolis, GO, Brazil. e-mail: ronangelini@yahoo.com.br

**Universidade Estadual de Maringá - UEM, Departamento de Biologia-NUPELIA, Av. Colombo, 5790, 87020-900 Maringá, PR, Brazil. 
scenarios and examined ecological potential to lead to increased production (Moreau et al., 2001; Villanueva \& Moreau, 2001; Schiemer et al., 2001). Modeling reservoirs may be more complicated because they are used by several stakeholders, and, in most of the cases, with contradictory needs (Angelini \& Petrere, 2000).

Presently, $90 \%$ of the energy consumed in Brazil is produced by dams and $70 \%$ of the dams are located in the Paraná River Basin (Okada et al., 1996). Although annual fishery yields in reservoirs of the Paraná River is low $\left(9.1 \mathrm{~kg} \mathrm{ha}^{-1}\right)$ relative to reservoirs in other parts of the world (Petrere, 1996; Miranda, 1999), fisheries are an important regional economic activity because they supply food for thousands of people.

In the Itaipu Reservoir, commercial fisheries started after its formation (since February 1984), and the number of fisherman along time has oscillated around 900 , of which $60 \%$ are permanent (Okada et al., 2005). Numerous studies have assessed the fishery in Itaipu Reservoir (Agostinho et al., 1994; Okada et al., 1996; Gomes \& Miranda, 2001; Miranda et al., 2000; Gomes et al., 2002; Petrere et al., 2002), but none adopted the food web approach.

In this study, we applied the ecosystem approach to data obtained in the Itaipu Reservoir. Energy flows were quanti-

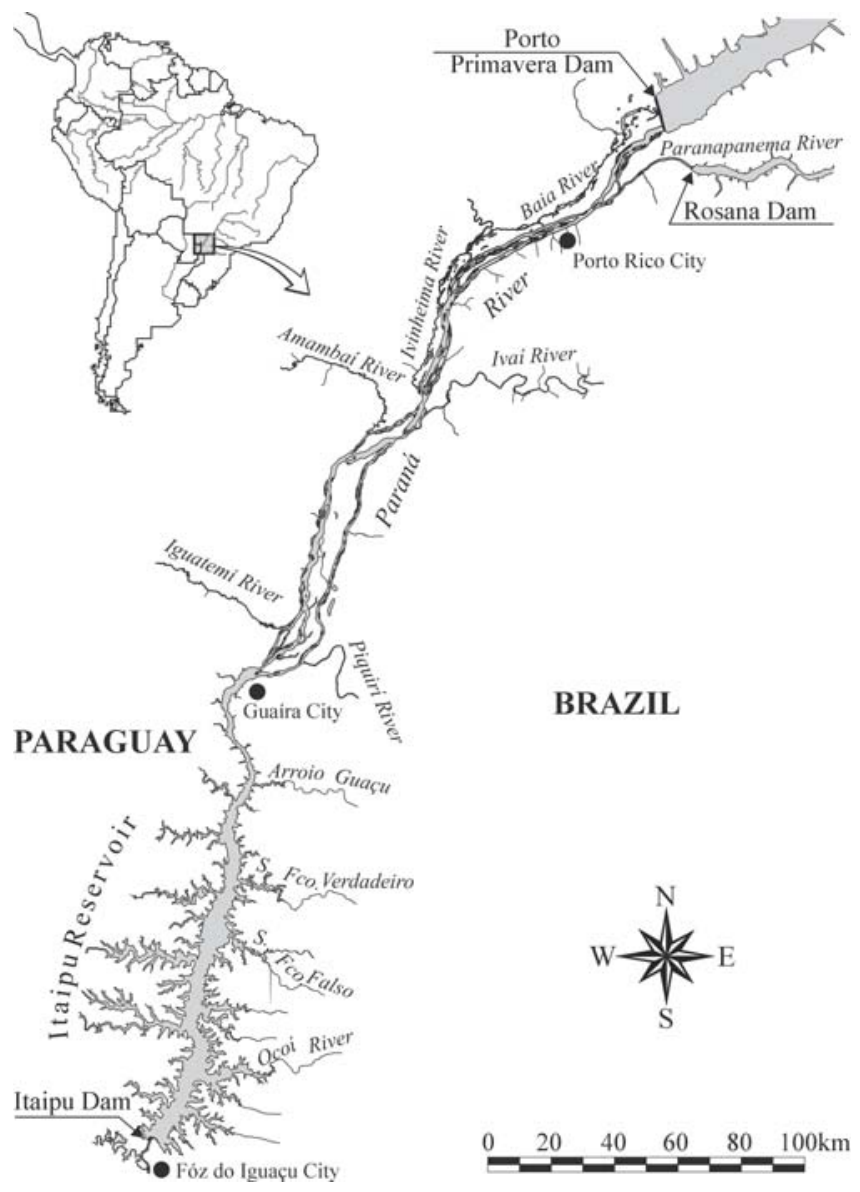

Fig. 1. Itaipu Reservoir, its tributaries and the upper Paraná River Floodplain upstream (spawning areas for the reservoir migratory fish species). fied for two different periods (two steady-state models; 198387 and 1988-92). These models were compared in order to evaluate trophic interactions and aging effects. In addition, simulations considering effects of increasing fishing effort were done. We expect to answer the following questions: i) is the ecosystem approach useful to guide management of reservoir fisheries? and ii) is there, for the Itaipu Reservoir, any sign of stability? For the second question, we assume if there is no difference between the models, some sort of stability was already reached.

\section{Methods}

\section{Study Area}

The Itaipu Dam was concluded in October 1982 and it is located on the Brazilian- Paraguayan border (Fig. 1). The resulting Itaipu Reservoir has a surface area of $1350 \mathrm{~km}^{2}$, mean depth of $22 \mathrm{~m}$ and an average hydraulic retention time of approximately 40 days. It is considered mesotrophic water body with low phosphorus concentration and limited primary production (Andrade et al., 1988).

Upstream from the Itaipu Reservoir, there is an extensive floodplain, which represents the last non-dammed stretch of the Paraná River within the Brazilian territory. This stretch is very important for fish populations in the reservoir because many migratory species use the area as nursery (Baumgartner et al., 2004).

\section{Model}

We used Ecopath software (Christensen \& Pauly, 1993) to construct food web models. Ecopath combines the work developed by Polovina (1984) to estimate biomass and consumption of various elements of an aquatic ecosystem, based on the theory for analysis of flows among elements of an ecosystem (Ulanowicz, 1986). A basic requirement in these models is that input to each group is equal to output (equilibrium conditions). Then, a series of biomass budget equations are determined for each group as:

Production - all predation on each grouping - non-predatory mortality - all exports $=0$

The resulting budget equations are transformed into simultaneous equations following the formula:

$$
0=\mathrm{B}_{i} * \mathrm{~PB}_{i} * \mathrm{EE}_{i}-\mathrm{Y}_{i}+{ }_{j}\left(\mathrm{~B}_{j} * \mathrm{QB}_{j} * \mathrm{DC}_{j i}\right)
$$

where: $\mathrm{B}_{i}$ is the biomass of $(i), \mathrm{PB}_{i}$ is the production/biomass ratio of $(i)$ that is equal to total mortality rate $\left(\mathrm{Z}_{i}\right), \mathrm{EE}_{i}-$ ecotrophic efficiency, i.e. fraction of production of $(i)$ that is consumed, $\mathrm{Y}_{i}$ is the yield of $(i)$ or its catch in weight, $\mathrm{B}_{j}$ is the biomass of predators, $\mathrm{QB}_{j}$ is food consumption per unit of biomass for consumer $j$ and $\mathrm{DC}_{j i}$ is the fraction of $i$ in the diet of $j$.

Equation (1) was proposed by Walters et al. (1997) that modified the original model, including a routine (Ecosim), which allows simulating fisheries in several management scenarios. The data required for Ecopath with Ecosim were gath- 
ered and standardized to the unit ton* $\mathrm{km}^{-2}$ or ton* $\mathrm{km}^{-2 *} \mathrm{year}^{-1}$. Then, two Ecopath models were built, the ITAIPU-1, for the first period (1983-1987) and the ITAIPU-2, for the second pe$\operatorname{riod}(1988-1992)$.

\section{Data Source and model Components}

Length-frequency data for the most abundant species of the Itaipu Reservoir for the periods 1983-87 and 1988-1992 were obtained by NUPELIA (Research Nucleus in Limnology, Ichthyology and Aquaculture, Maringá State University, Brazil). In general, intense fishing surveys were carried out in the studied area using different combinations of fishing gears (for more details see Agostinho et al., 1994 and Agostinho et al., 2001).

Initial estimates of fish biomass were determined by the Ecotrophic Efficiency and Ecopath calculated the biomass. A high value ( 0.99 or 0.9$)$ was considered for fishes with trophic level as many as 2 or 2.5 due to the expected importance of these groups as food of several piscivores groups. For commercially important species, biomass values were calculated using VPA (Virtual Population Analysis). PB (or Z) values were estimated using FISAT (FAO-ICLARM 1996) and QB values by regression from Palomares \& Pauly (1998). For more details, see Angelini \& Agostinho (2005a, b).

Non-fish compartments estimates were made based on the literature. Phytoplankton was quoted in Andrade et al. (1988), Thomaz (1991) and Thomaz et al. (1997). Other sources were used: Cook (1990), Thomaz \& Bini (1999), Thomaz et al. (1999) for macrophytes; Rodrigues (1998) for periphyton; Cummins \& Klug (1979), Takeda et al. (1997), Mihuc (1997) and Brey (1999) for benthos; Tundisi (1986), Sipaúba - Tavares et al. (1994), Angelini et al. (1996) and Lansac - Tôha et al. (1997) for zooplankton; Silva Jr. (1998) for insects. Data were transformed in ton* $\mathrm{km}^{-2}$ using a conversion table (Optiz, 1991).

Diet composition matrix for fish was established according to Hahn et al. (1997) and Agostinho et al. (1997), whose data partly refers to the Upper Paraná River Floodplain, which presents a similar fish fauna.

Thirty two components were used for each model, as follows: $i)$ seven are non-fish compartments; $i i)$ three are aggregated by feeding habit (Other detritivores, Other insectivores, Other omnivores), because in Itaipu there are 80 fish species; iii) in order to get a balanced model, two compartments are composed of grouped species: Group 1: Pimelodus maculatus (Lacepéde, 1803), Plagioscion squamosissimus (Heckel, 1840) and Serrasalmus marginatus (Valenciennes, 1836), Group 2: Ageneiosus ucayalensis (Casteunal, 1855), Other piscivores, Zungaro zungaro (Humboldt, 1821) and Pseudoplatystoma corruscans (Spix \& Agassiz, 1829). These groupings helped to balance the models, minimizing redundancy between piscivores groups (Angelini \& Agostinho, 2005b); iv) other components are: Loricaria sp., Schizodon boreilii (Boulenger, 1900), Hypostomus spp, Prochilodus lineatus (Valenciennes, 1836), Iheringichthys labrosus (Lütken, 1874), Hypophthalmus edentatus (Spix \& Agassiz, 1829), Trachydoras paraguayensis (Eignmann \& Ward, 1907), Leporinus friderici (Bloch, 1794),
Table 1. Parameters of the ECOPATH models for the Itaipu Reservoir in the two periods: ITAIPU-1 (83-87) and ItaIPU-2 (88-92). B (Biomass); PB (Production/Biomass); QB (Consumption/Biomass); EE (Ecotrophic Efficiency). Values in brackets are estimated by Ecopath. ${ }^{*}$ Species Grouping: Group 1: $P$. maculatus, P. squamosissimus, S. marginatus; Group 2: A. ucayalensis; Other piscivores, Z. zungaro, P. corruscans.

\begin{tabular}{|c|c|c|c|c|c|c|c|c|}
\hline \multirow{2}{*}{$\begin{array}{c}\text { Calibrated } \\
\text { Parameters } \\
\text { Groups Periods }\end{array}$} & \multicolumn{2}{|c|}{$\mathrm{B}\left(\mathrm{t} \mathrm{km}{ }^{-2}\right)$} & \multicolumn{2}{|c|}{ PB $\left(\right.$ year $\left.^{-1}\right)$} & \multicolumn{2}{|c|}{ QB $\left(\right.$ year $\left.^{-1}\right)$} & \multicolumn{2}{|c|}{$\mathrm{EE}$} \\
\hline & $83-87$ & $88-92$ & $83-87$ & $88-92$ & $83-87$ & $88-92$ & $83-87$ & $88-92$ \\
\hline Phytoplankton & $(0.36)$ & $(0.28)$ & 250.0 & 250.0 & - & - & 0.90 & 0.90 \\
\hline Macrophytes & 100.0 & 100.0 & 30.0 & 30.0 & - & - & $(0.06)$ & $(0.03)$ \\
\hline Periphyton & 14.80 & 14.80 & 40.0 & 40.0 & - & - & $(0.16)$ & $(0.17)$ \\
\hline Benthos & 4.80 & 4.80 & 10.4 & 10.4 & 40.0 & 40.0 & $(0.22)$ & $(0.26)$ \\
\hline Insects & $(1.72)$ & $(1.57)$ & 25.0 & 25.0 & 250.0 & 250.0 & 0.70 & $(0.10)$ \\
\hline Zooplankton & $(0.52)$ & $(0.38)$ & 54.0 & 55.0 & 250.0 & 250.0 & 0.70 & $(0.22)$ \\
\hline Loricaria sp. & $(0.08)$ & $(0.05)$ & 4.5 & 6.0 & 45.0 & 60.0 & 0.99 & 0.99 \\
\hline Schizodon borelii & $(0.06)$ & $(0.06)$ & 6.5 & 5.0 & 55.0 & 50.0 & 0.99 & 0.99 \\
\hline Hypostomus spp & $(0.17)$ & $(0.11)$ & 3.8 & 3.5 & 35.0 & 35.0 & 0.99 & 0.99 \\
\hline $\begin{array}{l}\text { Prochilodus } \\
\text { lineatus }\end{array}$ & 0.60 & $(0.48)$ & 4.2 & 3.9 & 25.0 & 45.0 & $(0.63)$ & $(0.96)$ \\
\hline $\begin{array}{l}\text { Iheringichthys } \\
\text { labrosus }\end{array}$ & $(0.04)$ & $(0.08)$ & 4.8 & 2.8 & 45.0 & 19.4 & 0.99 & 0.99 \\
\hline $\begin{array}{l}\text { Hypophthalmus } \\
\text { edentatus }\end{array}$ & 0.65 & $(0.65)$ & 3.6 & 1.6 & 20.9 & 20.9 & $(0.42)$ & $(0.63)$ \\
\hline $\begin{array}{l}\text { Trachydoras } \\
\text { paraguayensis }\end{array}$ & $(0.04)$ & - & 3.6 & - & 55.0 & - & 0.99 & - \\
\hline $\begin{array}{l}\text { Leporinus } \\
\text { friderici }\end{array}$ & $(0.06)$ & $(0.21)$ & 1.7 & 2.8 & 18.9 & 19.0 & 0.99 & 0.99 \\
\hline $\begin{array}{l}\text { Leporinus } \\
\text { obtusidens }\end{array}$ & $(0.72)$ & 0.38 & 2.7 & 4.0 & 18.6 & 30.0 & 0.99 & $(0.92)$ \\
\hline $\begin{array}{l}\text { Parauchenipterus } \\
\text { galeatus }\end{array}$ & $(0.18)$ & $(0.47)$ & 5.1 & 1.4 & 26.2 & 26.2 & 0.99 & 0.99 \\
\hline $\begin{array}{l}\text { Pterodoras } \\
\text { granulosus }\end{array}$ & $(0.54)$ & 0.40 & 2.5 & 2.1 & 20.0 & 16.1 & $(0.69)$ & $(0.62)$ \\
\hline $\begin{array}{l}\text { Astyanax } \\
\text { altiparanae }\end{array}$ & (1.66) & $(1.14)$ & 2.2 & 2.6 & 10.9 & 10.9 & 0.99 & 0.99 \\
\hline $\begin{array}{l}\text { Auchenipterus } \\
\text { nuchalis }\end{array}$ & 0.06 & 0.08 & 6.5 & 3.0 & 50.0 & 10.0 & $(0.81)$ & $(0.98)$ \\
\hline $\begin{array}{l}\text { Acestrorhyncus } \\
\text { lacustris }\end{array}$ & 0.04 & 0.12 & 5.5 & 2.8 & 25.0 & 9.5 & $(0.81)$ & $(0.97)$ \\
\hline Group 2* & 0.41 & 0.31 & 2.4 & 2.1 & 9.1 & 7.7 & $(0.94)$ & $(0.93)$ \\
\hline Group 1* & 1.20 & 1.03 & 2.1 & 1.4 & 9.2 & 6.2 & $(0.58)$ & $(0.77)$ \\
\hline $\begin{array}{l}\text { Hoplias } \\
\quad \text { malabaricus }\end{array}$ & 0.04 & 0.09 & 4.9 & 2.4 & 17.0 & 8.7 & $(0.69)$ & $(0.81)$ \\
\hline $\begin{array}{l}\text { Pinirampus } \\
\text { pirinampu }\end{array}$ & 0.11 & 0.11 & 2.0 & 1.4 & 7.0 & 5.0 & $(0.89)$ & $(0.92)$ \\
\hline $\begin{array}{l}\text { Rhaphiodon } \\
\text { vulpinus }\end{array}$ & 0.09 & 0.18 & 3.2 & 1.6 & 13.0 & 7.0 & $(0.85)$ & $(0.98)$ \\
\hline $\begin{array}{c}\text { Moenkhausia } \\
\text { intermedia }\end{array}$ & 0.16 & - & 5.0 & - & 26.0 & - & $(0.92)$ & - \\
\hline $\begin{array}{l}\text { Megalancistrus } \\
\text { parananus }\end{array}$ & - & 0.35 & - & 4.00 & - & 30.0 & - & $(0.57)$ \\
\hline Rhinelepis aspera & - & $(0.56)$ & - & 1.44 & - & 14.0 & - & 0.99 \\
\hline Other detritivores & $(0.31)$ & $(0.07)$ & 4.3 & 4.30 & 43.0 & 43.0 & 0.99 & 0.99 \\
\hline Other omnivores & $(0.56)$ & $(0.67)$ & 5.0 & 5.0 & 33.0 & 33.0 & 0.99 & 0.99 \\
\hline Other insectivores & $(0.41)$ & $(0.25)$ & 3.9 & 3.9 & 27.0 & 27.0 & 0.99 & 0.99 \\
\hline Detritus & - & - & - & & - & & $(0.14)$ & $(0.13)$ \\
\hline
\end{tabular}

Leporinus obtusidens (Valenciennes, 1836), Pterodoras granulosus (Valenciennes, 1836), Astyanax altiparanae (Garutti \& Britski, 2000), Auchenipterus nuchalis (Spix \& Agassiz, 1829), Acestrohyncus lacustris (Lütken, 1875), Hoplias malabaricus (Bloch, 1794), Pinirampus pirinampu (Spix \& Agassiz, 1829), Rhaphiodon vulpinus (Spix \& Agassiz, 1829), Moenkhausia intermedia (Eignmann, 1908) Megalancistrus parananus (Peters, 1881), Rhinelepis aspera (Spix \& Agassiz, 1829). 
Table 2. Trophic level (TL) and diet composition of the compartments for ECOPATH in the Itaipu Reservoir. See Groups in Table 1.

\begin{tabular}{|c|c|c|c|c|c|c|c|c|c|c|c|c|c|c|c|c|c|c|c|c|c|c|c|c|c|c|c|c|c|c|}
\hline TL & & Prey/ Predator & 4 & 5 & 6 & 7 & 8 & 9 & 10 & 11 & 12 & 13 & 14 & 15 & 16 & 17 & 18 & 19 & 20 & 21 & 22 & 23 & 24 & 25 & 26 & 27 & 28 & 29 & 30 & 31 \\
\hline 1.0 & 1 & Phytoplankton & & & .5 & .1 & .3 & .2 & .15 & & .3 & & .05 & .05 & & .1 & .1 & & & & & & & & .1 & & .1 & & & \\
\hline 1.0 & 2 & Macrophytes & & .2 & & & .7 & & & & & & .3 & .3 & .4 & .5 & .2 & & & & & & & & & .2 & .2 & & & \\
\hline 1.0 & 3 & Periphyton & .5 & & & & & & & .1 & & & & & & & & & & & & & & & & & .05 & & .1 & .1 \\
\hline 2.0 & 4 & Benthos & & & & .1 & & & .15 & .35 & & & .05 & .05 & & .1 & & & & .05 & & & & & .1 & & .15 & .1 & & .1 \\
\hline 2.0 & 5 & Insects & & & & .2 & & & & .2 & & .15 & .2 & .2 & .6 & .1 & .3 & .7 & & .02 & & & & & .1 & .6 & .3 & .2 & & \\
\hline 2.0 & 6 & Zooplankton & & & & & & & & .1 & .7 & .3 & & & & .1 & .1 & .2 & & .03 & & & & & & .1 & .1 & .7 & & \\
\hline 2.3 & 7 & Loricaria sp. & . & & & & & & & & & & & & & & & & .1 & & .05 & & .1 & & & & & & & \\
\hline 2.0 & 8 & S. borelli & & & & & & & & & & & & & & & & & .1 & & .05 & & .1 & & & & & & & \\
\hline 2.0 & 9 & Hypostomus spp. & & & & & & & & & & & & & & & & & & .05 & & & .1 & & & & & & & \\
\hline 2.2 & 10 & P. lineatus & & & & & & & & & & & & & & & & & & & .1 & .2 & & .2 & & & & & & \\
\hline 2.7 & 11 & I. labrosus & & & & & & & & & & & & & & & & & .2 & .15 & & & & & & & & & & \\
\hline 2.7 & 12 & H. edentatus & & & & & & & & & & & & & & & & & & & .15 & & & & & & & & & \\
\hline 2.5 & 13 & T.paraguayensis & & & & & & & & & & & & & & & & & & & & & .2 & & & & & & & \\
\hline 2.6 & 14 & L. friderici & & & & & & & & & & & & & & & & & & .05 & & & .15 & & & & & & & \\
\hline 2.6 & 15 & L. obtusidens & & & & & & & & & & & & & & & .1 & & & & & .2 & & & & & & & & \\
\hline 2.6 & 16 & P. galeatus & & & & & & & & & & & & & & & & & & .05 & & & .15 & .2 & & & & & & \\
\hline 2.3 & 17 & P. granulosus & & & & & & & & & & & & & & & & & & .05 & & .2 & .1 & & & & & & & \\
\hline 2.8 & 18 & A. altiparanae & & & & & & & & & & & .1 & .1 & & & & & .2 & .1 & .1 & & .1 & .2 & & & & & & \\
\hline 3.0 & 19 & A. nuchalis & & & & & & & & & & & & & & & & & .1 & & .05 & & & & & & & & & \\
\hline 3.6 & 20 & A. lacustris & & & & & & & & & & & & & & & & & & & .05 & .1 & & .1 & & & & & & \\
\hline 3.4 & 21 & Group 1 & & & & & & & & & & & & & & & & & & .1 & .1 & & & & & & & & & \\
\hline 3.9 & 22 & Group 2 & & & & & & & & & & & & & & & & & & .05 & .1 & & & & & & & & & \\
\hline 3.8 & 23 & H. malabaricus & & & & & & & & & & & & & & & & & & & & .2 & & & & & & & & \\
\hline 3.3 & 24 & P. pirinampu & & & & & & & & & & & & & & & & & & & .05 & & & & & & & & & \\
\hline 3.7 & 25 & R. vulpinus & & & & & & & & & & & & & & & & & & & .05 & & & .1 & & & & & & \\
\hline 2.2 & 26 & other ilio/det & & & & & & & & & & & & & & & & .1 & .1 & & & & & .1 & & & & & & \\
\hline 2.7 & 27 & other insectiv & & & & & & & & & & & & & & & & & .1 & .1 & & .1 & & .1 & & & & & & \\
\hline 2.6 & 28 & other omnivores & & & & & & & & & & & .1 & .1 & & & .1 & & .1 & .05 & .05 & & & & & & & & & \\
\hline 3.0 & 29 & M. intermedia & & & & & & & & & & & & & & & & & & & & & & & & & & & & \\
\hline 2.0 & 30 & M. parananus & & & & & & & & & & & & & & & .05 & & & & .05 & & & & & & & & & \\
\hline 2.1 & 31 & R. aspera & & & & & & & & & & & & & & & .05 & & & & .05 & & & & & & & & & \\
\hline 1.0 & 32 & Detritus & .5 & .8 & .5 & .6 & & .8 & .7 & .25 & & .55 & .2 & .2 & & .1 & & & & .15 & & & & & .7 & .1 & .1 & & .9 & .8 \\
\hline
\end{tabular}

\section{Comparisons and simulations}

The ITAIPU-1 (1983-1987) and ItAIPU-2 (1988-1992) models were compared using some ecosystem key features described by Odum (1969). After, using Ecopath with Ecosim, we simulated the ITAIPU-1 model (applying the same landing of ITAIPU2) for five years, that resulted in the Itaipu-SIM model and showed ecosystem's conditions for 1992. So, biomasses of this later model were compared, through paired t test, with the biomasses of the ITAIPU-2 model (1988-1992). This was done in order to validate the model. In addition, the ITAIPU-2 model was simulated, increasing fishing effort for some compartments, and these results were compared with mono-specific stock assessment models, published in Agostinho et al. (1999) and with landing data published in Okada et al. (2005).

Original landing from 1998, were put in subroutine "Input-Landing" of the Ecopath and used to calculate initial fishing effort. Landing data were described in ton* $\mathrm{km}^{-2 *}$ year $^{-1}$ as following: Prochilodus lineatus: 0.19, Hypophthalmus edentatus: 0.3, Pterodoras granulosus: 0.18, Hoplias malabaricus: 0.02, Pinirampus pirinampu: 0.02 and Raphiodon vulpinus: 0.04, Group 1: 0.24, Group 2: 0.05 .

\section{Results}

Estimates of biomass, production and consumption of the groups are presented in Table 1 for the two models (ITAIPU-1 and ITAIPU-2) and Table 2 summarizes the diet composition and trophic level for both models.
Apparently, the fishing activity conducted in the Itaipu Reservoir does not alter the ecosystem as a whole because attributes that indicate ecosystem maturity are similar in the two models (Table 3).

Biomasses resulting of simulation in ITAIPU-1 (1983-87), for five years, were compared to compartment biomasses of ITAIPU-2 (1988-1992), by paired $t$ test, and difference was not significant $(t=0.52, \mathrm{p}=0.60)$, validating the simulation.

Fishing effort original, based in landing data from 1998, was multiplied by 2,3 and 4 in order to simulate different fishery scenarios (Figs. 2a - 2b). It was possible to observe an increment in the biomass of $P$. lineatus that can be explained

Table 3. Attributes of ecosystem maturity for the Itaipu reservoir models. Trend indicates the expected behavior by Odum (1969).

\begin{tabular}{lccc}
\hline \multicolumn{1}{c}{ Attributes } & $\begin{array}{c}\text { ITAIPU-1 } \\
1983-87\end{array}$ & $\begin{array}{c}\text { ITAIPU-2 } \\
1988-92\end{array}$ & $\begin{array}{c}\text { Trend } \\
\text { (expected) }\end{array}$ \\
\hline $\begin{array}{l}\text { Total Primary Production/ } \\
\text { Total Respiration }\end{array}$ & 6.3 & 6.8 & $=1$ \\
Total Primary Production/ & 28.24 & 28.23 & Diminishing \\
Total Biomass & & & \\
Biomass supported/ Energy Flow & 0.016 & 0.016 & Increasing \\
Finn cycling index (\%) & 1.92 & 1.78 & Increasing \\
Total number of cycles & 663 & 801 & Increasing \\
Mean length of cycles & 5.01 & 5.19 & Increasing \\
Transfer efficiency (\%) & 8.5 & 9.6 & Increasing \\
Flow from detritus (\%) & 0.51 & 0.51 & Increasing \\
Ascendency (\%) & 46.0 & 46.8 & Diminishing \\
Overhead (\%) & 54.0 & 53.2 & Increasing \\
\hline
\end{tabular}


by the reduction in biomass of its main predator $H$. malabaricus (Trophic Level $(\mathrm{TL})=3.8$ ). Pinirampus pirinampu $(\mathrm{TL}=3.3)$ had its biomass increased probably because of the decreasing biomass of its competitor due to its higher catch (Fig. 2a). Group 1, P. lineatus and P. pirinampu did not alter their biomasses (Fig. 2a) and, therefore, their fishing effort and landing could increase (Fig. 2b).

Figure 3 shows simulated catch and observed catch data if fishing effort remains the same as 1998 (relative for landing of 1998). In general, simulated values were greater than observed values, but it is clear that both curves present similar trend. This overall conclusion is confirmed by Fig. 4, in which simulated and observed total landings are visualized.

\section{Discussion}

Information on all non-fish compartments and diet composition is scarce in most South American reservoirs and the case of the Itaipu is not different. In order to overcome this problem, we used the same information for non-fish compartments in both models. In fact, this simplification may be useful because it may allow a better understanding of the fisheries dynamics by standardizing non-fish parameters whereas
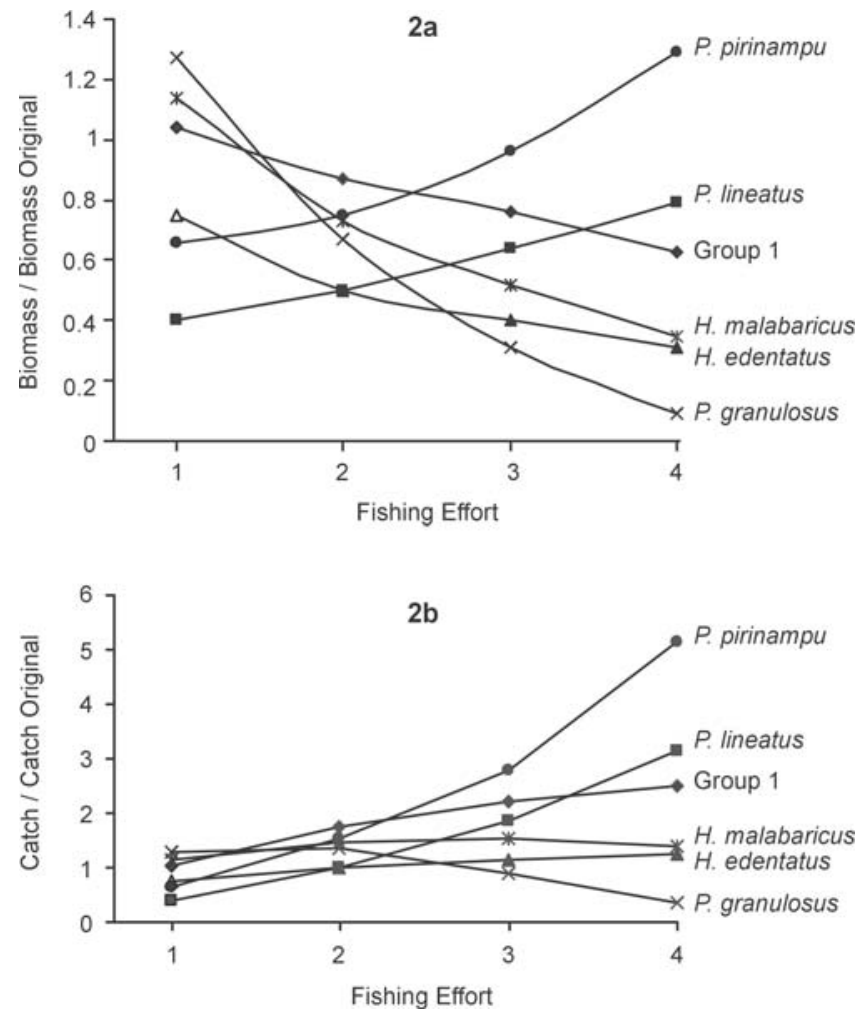

Fig. 2. Relative biomass (2a) and relative catch (2b) of the main species of the ITAIPU- 2 model, with increasing of fishing effort. Fishing effort $=1$ is equivalent to that registered in 1998. This value was multiplied by 2,3 and 4, in order to get other fisheries scenarios. Simulations made in Ecopath with Ecosim (Subroutine: Run Ecossim, module: Results). the input fish species values were changed. Parameter estimates results from Ecopath appear reasonable, especially for fish biomass differences between ITAIPU- 1 and ITAIPU- 2 .

Resilience of disturbed environments may be evaluated by ecosystem attributes. Input fishing on second model did not change whole results (Table 3). Apparently, ecosystem of Itaipu Reservoir represented by models is an accommodation phase and therefore, models did not detect any trend related to aging. Then, it can be assumed that the reservoir achieved some level of stability, but still far from maturity. This opinion is corroborated by limnological data (Agostinho et al., 1999b) and by little fluctuations in the composition of trophic groups (Hahn et al., 1998).

Aging in ecosystems was discussed in Lindeman (1942), who ventured to diagram a hypothetical "hydrosere". However, the identification of phases in a reservoir appears to be completely different than in a lake, because reservoirs are formed fast. In addition, opportunistic species pre-adapted to colonize lentic environments, like the exotic $P$. squamosissimus in the Itaipu Reservoir, could control and stabilize ecological succession. Besides, dam operation may also alter equilibrium of communities, which may lead the ecosystem represented by the Itaipu Reservoir to an intermediate level of development.
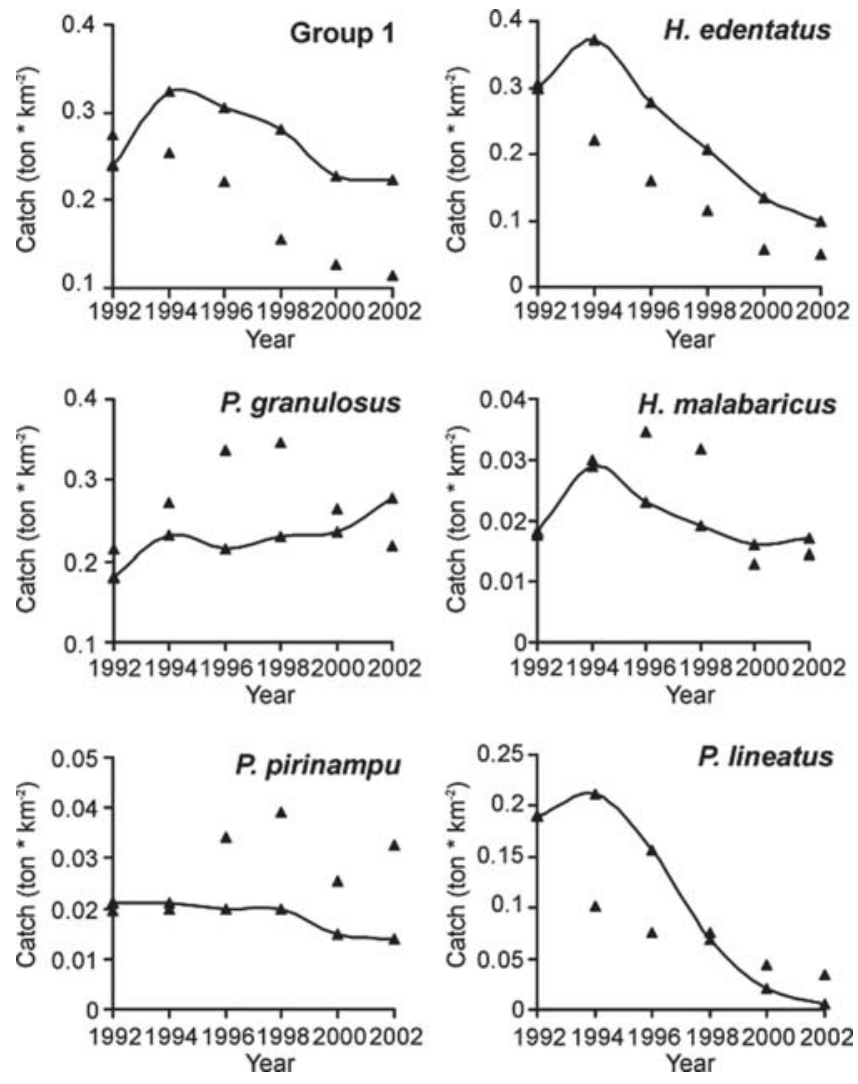

Fig. 3. Simulated catches (solid line) and catch values observed (triangles) for the main species of the ITAIPU-2 model, under the same fishing effort of 1998. Simulations made in Ecopath with Ecosim (Subroutine: Run Ecossim, module: Results). 
Mean trophic level of the catch (yield) in ITAIPU-2 is high (2.8) and gross efficiency (catch/net primary production) is 10 times lower than a Sri Lanka reservoir (Moreau et al., 2001). This low efficiency and yield can be attributed to the low number of lacustrine - pre adapted species, long food chains, high number of predatory species and low primary production (Miranda et al., 2000, Gomes \& Miranda 2001, Gomes et al., 2002).

Results obtained in this study show that the Itaipu Reservoir is more near maturity than the Broa Reservoir (Angelini \& Petrere, 1996) because it presents higher values of total primary production/total respiration, Finn cycling index and overhead (Table 3). However, reservoir Ria Formosa lagoonal system is closer to maturity than the Itaipu because it has an important detritus support food chain (Gamito \& Erzini, 2005).

Validation is an essential step in modeling procedure and it tests model against an independent set of data (JØrgensen, 1994). Simulation in ITAIPU-1 (1983-1987), for five years, resulted in biomass values similar to the ones obtained in ITAIPU2 (1988-1992) (not significant paired $t$ test). This enabled us to validate the Ecopath with Ecossim routine and, consequently, to make more comfortable the simulations on ITAIPU-2.

Results obtained through simulations are very close to mono-specific stock assessment data for the same species and periods (Agostinho et al., 1999a). Thus, apparently, it is possible to increase fishing effort, towards $P$. pirinampu and $P$. lineatus (Fig. 2). Also, P. pirinampu biomass shows tendency to increase whereas $P$. granulosus and $H$. edentatus biomasses would be affected and decreased, if fishing effort remains the same (Fig. 3). Alteration in river level, specially the control of floods prompted by dams located upstream from the Itaipu Reservoir appears to be the main cause of these findings (Agostinho et al., 2004).

Agostinho et al. (1999a) and Okada et al. (2005) show that P. squamosissimus and P. maculatus (Group 1) fisheries are near to maximum sustainable yield. Nevertheless, Group 1 biomass is the most stable (Fig. 3) probably because $P$. squamosissimus is abundant. Differences between simulated

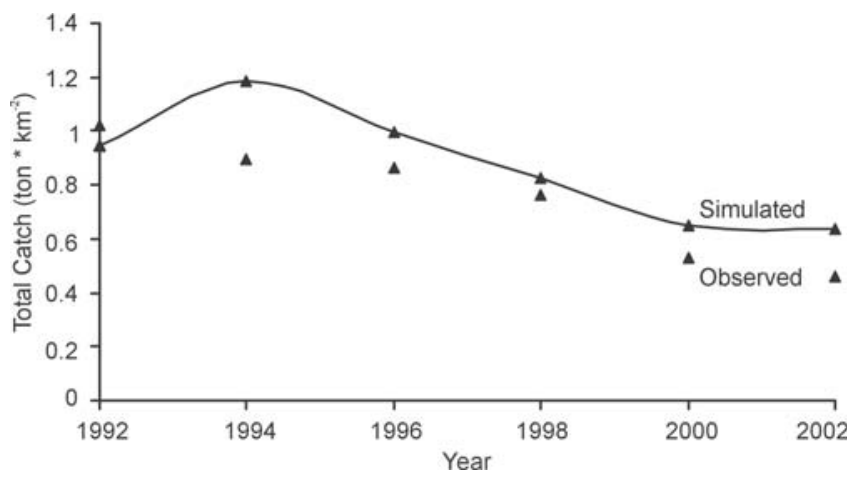

Fig. 4. Simulated Total catch (solid line) and catch values observed (triangles). Simulations performed on ITAIPU-2 model, under constant fishing effort (values were close to 1998). Simulations made in Ecopath with Ecosim (Subroutine: Run Ecossim, module: Results). and observed data to Group 1 are high because we do not have landing data of $S$. marginatus, which is explored commercially only when other species are lacking and sometimes this species is discarded due to low market price. Moreover, in general, groupings in food webs present more stable results than single species does (Naeem \& Li, 1997; Solow \& Beet, 1998).

Simulated trend in catches from ITAIPU- 2 overestimated observed values (Fig. 4), but with same tendency, showing that model could support and to help stock assessment and fishery management. Even so, this model could be improved with quantitative studies in non-fish compartments (for example, bacterioplankton which is essential to understand recycling) and feeding data of juveniles of top predators that would allow splitting top predators into two boxes (juveniles and adults).

Many authors believe that tropical ecosystems are environments where biotic and abiotic oscillations are annual and sometimes unexpected. But between 1983 and 2003, Itaipu Reservoir appears to get some stability although far from maturity. Itaipu can support fishing activity with increasing fishing effort of some species since, during the spawning period of majority of species, fishery continues prohibited.

\section{Acknowledgements}

This study is part of R. Angelini's Doctoral Thesis at the Graduate Course of Inland Water supported by NUPELIA Research Nucleus in Limnology, Ichthyology and Aquaculture, and Department of Biology, Maringá State University, Brazil - under the advice of Miguel Petrere Jr. who made valuable comments.

\section{Literature Cited}

Agostinho, A. A., L. C. Gomes \& M. Zalewski. 2001. The importance of floodplains for the dynamics of fish communities of the upper river Paraná. Ecohidrology \& Hydrobiology, 1:209-217.

Agostinho, A. A., A. M. Ambrósio, V. S. Ferreira, E. F. Oliveira, E. K. Okada \& H. I. Suzuki. 1999a. Reservatório de Itaipu - aspectos biológicos e socio-econômicos da pesca. Relatório anual 1997/98. Ed. UEM- NUPELIA, Maringá.

Agostinho, A. A., L. E. Miranda, L. M. Bini, L. C. Gomes, S. M. Thomaz \& H. I. Suzuki. 1999b. Patterns of Colonization in neotropical reservoirs, and prognoses on aging. Pp. 227-265. In: Tundisi, J. G. \& M. Straskraba (Eds.) Theoretical reservoir ecology and its applications, Backhuys Publishers, 585p.

Agostinho, A. A., N. S. Hahn, L. C. Gomes \& L. M. Bini. 1997. Estrutura trófica. Pp. 229-248. In: Vazzoler, A. E. M., A. A. Agostinho \& N. S. Hahn (Eds.) A planície de inundação do alto rio Paraná: aspectos físicos, biológicos e sócio-econômicos. EdUEM. Maringá. 460p.

Agostinho, A. A., E. K. Okada \& L. C. Gomes. 1994. Composição e Rendimento Específico da pesca Comercial no Reservatório de Itaipu Pp. 1-15. In: Agostinho, A. A. \& E. K. Okada (Eds.) A pesca no reservatório de Itaipu. EdUEM. Maringá. 80p.

Agostinho, A. A., H. F. Julio \& M. Petrere. 1994. Itaipu reservoir (Brazil): Impacts of the impoundment on the fish fauna and fisheries. Pp. 171-184. In: I. G. Cowx (Ed.) Rehabilitation of Freshwater Fisheries. Fishing New Books, Blackwell Science, Oxford. 413p. 
Agostinho, A. A., L. C. Gomes, S. Veríssimo \& E. K. Okada. 2004. Flood regime, dam regulation and fish in the Upper Paraná River: effects on assemblages attibutes, reproduction and recruitment. Reviews in Fish Biology and Fisheries, 14:11-19.

Andrade, L. F., R. F. Brunkow, C. F. Xavier \& L. L. Domingues. 1988. Fitoplâncton e características físico-químicas do reservatório de Itaipu (BR). Pp. 205-268. In: J. G. Tundisi (Ed.) Limnologia e manejo de represas. Série Monografias em Limnologia, v. 1, EESC/USP/CRHEA/ACIESP, São Paulo.

Angelini, R. \& A. A. Agostinho. 2005a. Differences in Biological Statistics of Fish Species of the Upper Paraná River Floodplain and Itaipu Reservoir (Brazil). Naga - The World Fisheries Center NewsLetter, 28(1):53-57.

Angelini, R. \& A. A. Agostinho 2005b. Food web model of the Upper Paraná River Floodplain: description and aggregation effects. Ecological Modelling, 181:109-121.

Angelini, R. \& M. Petrere. 2000. A model for the plankton system of the Broa reservoir, São Carlos - Brazil. Ecological modelling, 126(2-3):131-137.

Angelini, R. \& M. Petrere. 1996. The ecosystem of the Broa Reservoir, São Paulo State, Brazil, as describe using the Ecopath. Naga, the ICLARM Quartely, 19:36-41.

Angelini, R., M. A. P. Abuabara \& A. C. Rietzler. 1996. Application of de Bernardi \& Di Cola model in a Argyrodiaptomus furcatus (zooplankton - copepod) from Broa Reservoir (SP-Brazil). Memorie dell'Istituto Italiano di Idrobiologia, 54:69-75.

Aoki, I. \& T. Mizushima. 2001. Biomass diversity and stability of food webs in aquatic ecosystems. Ecological Research, 16: 65-71.

Baumgartner, G., K. Nakatani, L. C. Gomes, A. Bialetzki, P. V. Sanches \& M. C. Makrakis. 2004. Identification of spawning sites and natural nurseries of fishes in the upper Paraná River, Brazil. Environmental Biology of Fishes, 71:115-125.

Brey, T. 1999. A collection of empirical relations for use in ecological modeling. Naga, The ICLARM Quartely, 22(3):24-28.

Christensen, V. 1995. Ecosystem maturity - towards quantification. Ecological Modelling, 77:3-32.

Christensen, V. \& D. Pauly. 1998. Changes in models of aquatic ecosystems approaching carrying capacity. Ecological applications, 8(1):104-109.

Christensen, V. \& D. Pauly. 1993. Trophic models of aquatic ecosystems. ICLARM. Manila. Philippines. 390p.

Christensen, V., S. Guénette, J. J. Heymans, C. J. Walters, R. Watson, D. Zeller \& D. Pauly. 2003. Hundred-year decline of North Atlantic predatory fishes. Fish and Fisheries, 4:1-24.

Cook, C. D. K. 1990. Origin, autoecology, and spread of some of the world's most troublesome aquatic weeds. Pp. 31-38. In: Pieterse, A. H. \& K. J. Murphy (Eds.) Aquatic weeds. The ecology and management of nuisance aquatic vegetation. Science Publications, Oxford. 350p.

Cushing, D. H. 1996. Towards a Science of Recruitment in Fish Populations. Ecology Institute Publishing. German. 485p.

Cummins, K. W. \& M. J. Klug. 1979. Feeding ecology of stream invertebrates. Annual Review Ecology Systematics, 10:147-172.

FAO. 2003. Fisheries management 2. The ecosystem approach to fisheries. FAO Technical Guidelines for Responsible Fisheries, 4, Suppl. 2 Roma, FAO, 112p.

FAO. 2002. FAO Yearbook. Fishery Statistics. Capture Production. Vol. 94/1, Roma, 642p.

FAO-ICLARM. 1996. Stock Assessment Tools. User's Manual Ed: FAO-ICLARM, Rome. 320p.

Gamito, S. \& K. Erzini. 2005. Trophic food web and ecosystem attributes of a water reservoir of the Ria Formosa (south Portugal). Ecological Modelling, 181:509-520.
Gomes, L. C., L. E. Miranda \& A. A. Agostinho. 2002. Fishery yield relative to chlorophyll a in reservoirs of the Upper Paraná River, Brazil. Fisheries Research, 55:335-340.

Gomes, L. C. \& L. E. Miranda. 2001. Riverine characteristics dictate composition of fish assemblages and limit fisheries in reservoirs of the Upper Paraná River. Regulated Rivers: Research \& Management, 17:67-76.

Hahn, N. S., A. A. Agostinho, L. C. Gomes \& L. M. Bini. 1998. Estrutura trófica da ictiofauna do reservatório de Itaipu (PR Brasil) nos primeiros anos de sua formação. Interciência, 23(5):299-305.

Hahn, N. S., I. F. Andrian, R. Fugi, V. L. L. Almeida. 1997. Ecologia trófica. Pp. 209-228. In: Vazzoler, A. E. M., A. A. Agostinho \& N. S. Hahn (Eds.) A planície de inundação do alto rio Paraná: aspectos físicos, biológicos e sócio-econômicos. EdUEM, Maringá. 460p.

Heymans, J. J., L. J. Shannon \& A. Jarre. 2004. Changes in the northern Benguel ecoystem over three decades: 1970s, 1980s, and 1990s. Ecological Modelling, 172:175-195.

Hilborn, R. \& C. J. Walters. 1992. Quantitative Fisheries Stock Assessment: Choice, Dynamics and Uncertainty. Chapman \& Hall Ed. London. 250p.

Hilborn, R., T. A. Branch, B. Ernst, A. Magnusson, C. V. MinteVera, M. D. Scheuerell \& J. L. Valero. 2003. State of the world's fisheries. Annual Review Environmental Resources, 28:358-399.

Jarre-Teichmann, A. 1998. The potential role of mass balance models for the management of upwelling ecosystems. Ecological Applications, 8(1):93-103.

JØrgensen, S. E. 1994. Fundamentals of Ecological Modelling. 2 ed. Elsevier - Amsterdam. 626p.

Lansac-Tôha, F. A., C. C. Bonecker, L. F. M. Velho \& A. F. Lima. 1997. Composição, distribuição e abundância da comunidade zooplanctônica. Pp. 117-155. In: Vazzoler, A. E. M., A. A. Agostinho \& N. S. Hahn (Eds.). A planície de inundação do alto rio Paraná: aspectos físicos, biológicos e sócio-econômicos. EdUEM, Maringá. 460p.

Lindeman, R. L. 1942. The trophic-dynamic aspect of ecology. Ecology, 23:399-418.

Mace, P. M. 2001. A new role for MSY in single-species and ecosystem approaches to fisheries stock assessment and management. Fish and Fisheries, 2:2-32.

Marshal, B. E. 1984. Predicting ecology and fish yields in African reservoirs from preimpoundment physico-chemical data. FAO CIFA Technical Papers, 12:1-26.

Mihuc, T. B. 1997. The functional trophic role of lotic primary consumers: generalist versus specialist strategies. Freshwater biology, 37:455-462.

Miranda, L. E. 1999. A typology of fisheries in large reservoirs of the United States. North American Journal Fisheries Management, 19:536-550.

Miranda, L. E., A. A. Agostinho \& L. C. Gomes. 2000. Appraisal of the selective properties of gill nets and implications for yield and value of the fisheries at the Itaipu Reservoir, BrazilParaguay. Fisheries Research, 45:105-116.

Moreau, J., M. C. Villanueva, U. S. Amarasinghe \& F. Schiemer. 2001. Trophic relationships and possible evolution of the production under various fisheries management strategies in a Sri Lanka reservoir. Pp. 201-214. In: De Silva, S. S. (Ed.) Reservoir and culture-based fisheries: biology and management. Canberra. 436p.

Müller, F. 1997. State-of-the-art in ecosystem theory. Ecological Modelling, 100:135-161. 
Naeem, S. \& S. Li. 1997. Biodiversity enhances ecosystem reliability. Nature 390:507-509.

Odum, E. P. 1969. The Strategy of ecosystem development. Science 104:262-270.

Okada, E. K., A. A. Agostinho \& M. Petrere. 1996. Catch and effort data and the management of the commercial fisheries of Itaipu reservoir in the upper Paraná river, Brazil. Pp. 154-161. In: Cowx I. G. (Ed.) Stock assessment in inland fisheries. Fishing New Books Blackwell Science, Oxford. 413p.

Okada, E. K., A. A. Agostinho \& L. C. Gomes. 2005. Spatial and temporal gradients in artisanal fisheries of a large neotropical reservoir: the Itaipu Reservoir, Brazil. Canadian Journal of Fisheries and Aquatic Sciences, 62:714-724.

Optiz, S. 1991. Quantitative models of trophic interactions in caribbean coral reefs. Unpublished PhD. dissertation. Christian - Albrechts - Universitat zu Kiel. 215p.

Palomares, M. L. \& D. Pauly. 1998. Predicting food consumption of fish populations as functions of mortality, food type, morphometrics, temperature and salinity. Marine and freshwater research, 49(5):447-453.

Petrere, M., A. A. Agostinho, E. K. Okada \& H. F. Júlio. 2002. Review of the fisheries in the Brazilian portion of the Paraná/ Pantanal basin. Pp. 123-143. In: Cowx, I. G. (ed.) Management and Ecology of Lake and Reservoir Fisheries. Fishing New Books, Blackwell Science, Oxford. 413p.

Petrere, M. 1996. Fisheries in large tropical reservoir in South America. Lakes \& Reservoirs: Research and Management, 2:11-133.

Pikitch, E. K., C. Santora, E. A. Babcock, A. Bakun, R. Bonfil, D. O. Conover, P. Dayton, P. Doukakis, D. Fluharty, B. Heneman, E. D. Houde, J. Link, P. A. Livingston, M. Mangel, M. K. McAllister, J. Pope \& K. J. Sainsbury. 2004. Ecosystem-Based Fisheries Management. Science, 305:346-347.

Polovina, J. J. 1984. Model of a coral reef ecosystem. Part I. The ECOPATH model and its application to French Frigate Shoals. Coral reefs, 3:1-11.

Rodrigues, L. 1998. Sucessão do perifíton na Planície de Inundação do Alto Rio Paraná: Interação entre nível hidrológico e regime hidrodinâmico. Unpublished $\mathrm{PhD}$ dissertation. Universidade Estadual de Maringá, Maringá. 177p.

Schiemer, F., J. Amarasinghe, J. Frouzova, B. Sricharoendham \& E. I. L. Silva 2001. Ecosystem structure and dynamics - A management basis for Asian reservoirs and lakes. Pp. 215-226. In: De Silva, S. S. (Ed.) Reservoir and Culture-based Fisheries: Biology and Management. Canberra. 436p.

Silva Júnior, U. L. 1998. Análise da produção pesqueira de um lago de várzea do Baixo Amazonas através de um modelo de balanço de massas. Unpublished Master Thesis. Instituto Nacional de Pesquisas da Amazônia, Manaus. 73p.
Sipauba-Tavares, L. H., M. A. Bachion \& O. Rocha. 1994. Estudo do crescimento populacional de três espécies zooplanctônicas em laboratório e o uso do plâncton na alimentação de alevinos de Oerochromi niloticus (tilápia) e Astyanax scabripinis (lambari). Revista UNIMAR, 16(3):189-201.

Solow, A. R. \& A. R. Beet. 1998. On lumping species in food webs. Ecology, 79(6):2013-2018.

Takeda, A. Y., G. Y. Shimizu \& J. Higuti. 1997. Variações espaçotemporais da comunidade zoobêntica. Pp. 157-177. In: A. E. M. Vazzoler, A. A. Agostinho, N. S. Hahn (ed.) A planície de inundação do alto rio Paraná: aspectos físicos, biológicos e sócio-econômicos. EdUEM. Maringá. 460p.

Thomaz, S. M. 1991. Influência do regime hidrológico (pulsos) sobre algumas variáveis limnológicas de diferentes ambientes aquáticos da planície de inundação do alto rio Paraná (MS Brasil). Unpublished Master thesis. Universidade Federal de São Carlos. 293p.

Thomaz, S. M. \& L. M. Bini. 1999. A expansão das macrófitas aquáticas e implicações para o manejo de reservatórios: um estudo da represa de Itaipu. Pp. 597-626. In: Henry R. (Ed.) Ecologia de reservatórios: estrutura, função e aspectos sociais. Ed.Fapesp e Fundibio. 799p.

Thomaz, S. M., L. M. Bini, M. C. Souza, K. K. Kita \& F. M. Camargo. 1999. Aquatic macrophytes of Itaipu reservoir, Brazil: survey of species and ecological considerations. Brazilian Archives of Biology and Technology, 42(1):15-22.

Thomaz, S. M., M. C. Roberto \& L. M. Bini. 1997. Caracterização limnológica dos ambientes aquáticos e influência dos níveis fluviométricos. Pp. 73-102. In: Vazzoler, A. E. M., A. A. Agostinho \& N. S. Hahn (Eds.) A planície de inundação do alto rio Paraná: aspectos físicos, biológicos e sócio-econômicos. EdUEM. Maringá. 460p.

Tundisi, J. G. 1986. The Lobo (Broa) ecosystem. Ciencia Interamericana, 25:18-31.

Ulanowicz, R. E. 1997. Ecology, the ascendent perspective. Columbia University Press. 202p

Ulanowicz, R. E. 1986. Growth and development: ecosystem phenomenology. Springer Verlag. NY. 190p.

Vasconcellos, M., S. Mackinson, K. Sloman \& D. Pauly. 1997. The stability of trophic mass-balance models of marine ecosystems: a comparative analysis. Ecological modelling, 100:125-134.

Villanueva, M. C. \& J. Moreau. 2001. Recent trends in the Lake Victoria fisheries assessed by ECOPATH. Pp 96-111. In: Cow, I.G. (ed.) Management and Ecology of Lake and Reservoir Fisheries. Fishing New Books. Blackwell Science. 436p.

Walters C., V. Christensen \& D. Pauly. 1997. Structuring dynamic models of exploited ecosystems from trophic mass-balance assessments. Reviews in Fish Biology and Fisheries, 7:139172. 